\title{
Book Review: Bhattacharyya, M. (2020). Rabindranath Tagore's Śäntiniketan Essays: Religion, Spirituality and Philosophy. London \& New York: Routledge
}

\author{
Dan Manolescu (Corresponding author) \\ Freelance ESL Instructor and Award-Winning Author, New York, USA \\ Email: dan.manolescu@att.net
}

Received: 11/01/2021

Accepted: $15 / 04 / 2021$

Published: 01/05/2021

Volume: 2 Issue: 3

How to cite this paper: Manolescu, D. (2021). Book Review: Bhattacharyya, M. (2020). Rabindranath Tagore's Śantiniketan Essays: Religion, Spirituality and Philosophy. London \& New York: Routledge. Journal of Practical Studies in Education, 2(3), 12-15

DOI: https://doi.org/10.46809/ipse.v2i3.25

Copyright (C) 2020 by author(s) and Global Talent Academy Ltd. This work is licensed under the Creative Commons Attribution International License (CC BY 4.0).

http://creativecommons.org/licenses/by/4.0/

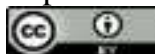

Rabindranath Tagore (7 May 1861 - 7 August 1941) was the first non-European poet and lyricist who received the most coveted of international awards, the Nobel Prize for Literature in 1913, "because of his profound sensitive, fresh and beautiful verse, by which, with consummate skill, he has made his poetic thought, expressed in his own English words, a part of the literature of the West." (www.nobelprize.org ) His most notable work highly praised and duly appreciated by The Swedish Academy was Gitanjali: Song Offerings (1912), a collection of poetry, but Tagore is also famous for having written a variety of genres, including drama, essay, novel, novella, short-story, dance-drama, and song.

While Tagore is recognized today mostly for his poetry, his short stories also proved to be extremely popular in what is called the Bengali-language version of the genre, and his essays reveal another facet of his personality, and that is his philosophical thought in which he distinguished himself as a language innovator. Rabindranath Tagore's Śāntiniketan Essays were translated and published by Medha Bhattacharyya in 2020 in a book celebrating Tagore's "fundamental meditations on life, nature, religion, philosophy, and the world at large." (Flyer, Bhattacharyya, 2020)

Right from the start, Bhattacharyya makes it very clear that "the standard scheme of transliteration with a slight variation was employed for the Romanization of Sanskrit, Pali and Bengali alphabets throughout this translation. This was to ensure that the non-Bengali or the international readership would be able to go through the text without much constraint." (Intro p. xiii)

The Introduction offers a glimpse into the great mind of Tagore, among whose philosophical essays written in Bengali, two titles stand out: Śāntiniketan, a collection of 152 lectures, and Dharma, comprising fifteen lectures. If we want to really comprehend the depth of his essays, especially the collection entitled Śantiniketan, we must understand Tagore's "life force of his deep recesses," (Bhattacharyya, 2020) and therefore it seems imperative that we delve into some important personal and professional events that took place in his life and shaped his thought.

Prior to the publication of Śantiniketan and Dharma, Tagore had already tried his pen writing essays which had philosophical strains, and they give us a chance to explore his thought at the time he was getting ready to deliver the Śantiniketan talks, which eventually were turned into the essays we know today. 
Tagore's literary accomplishments ranged from plays (The Genius of Valmiki, Sanyasi, or The Ascetic, The Sacrifice, Chitra: A Play in One Act, The King of the Dark Chamber, The Immovable, The Post Office, Red Oleander) to novels (The Eyesore, The Home and the World, Crosscurrents) to short stories (The Postmaster, The Fruitseller from Kabul, The Castaway, The Hungry Stones, The Devotee) to novellas (The Broken Nest). During his period abroad, Tagore also translated some of his own Bengali poems into English, beginning with Gitanjali: Song Offerings, The Crescent Moon, The Gardner, Fruit Gathering, and then adding Lover's Gift and Crossing. He started delivering his Śantiniketan lectures when he was 47 years old. According to Bhattacharayya, "These lectures started quite informally with a handful of young men at Śāntiniketan ashram among whom was Kshitimohan Sen, requesting Tagore to impart to them the knowledge attained through his dawn upāsanā at Śāntiniketan. Sen mentions that Tagore used to sit under the open sky at his ashram from around 3:00 a.m. to 3:30 a.m.in dyana," (Śäntiniketan 6) which, in the translator's view, was a time Tagore deemed to have been sacred to him. In January of 1935 he described these memorable moments in a letter to Rani Mahalanabish:

Many a time my own song seemed to be the composition of someone else just heard through me. The book Śntiniketan exactly appears like that - it is as if its words are beyond my sadhana and capacity. The first volume is just out - the words that I can hear while going through the proof of the second part are not mine, yet are mine ... so I may be praised only to that extent as is done to a well-made talking machine. (Translated by Bhattacharayya, Pal 6: 38, p. 7)

In a nutshell, Śäntiniketan (Abode of Peace) is a collection of 152 essays consisting of seventeen parts in two volumes. Medha Bhattacharyya selected to translate fifty essays from Śäntiniketan-"because they are not only rich in their contents but also because Tagore had conveyed such great truth in such a simple manner, made easy for readers of all age groups, culture and race to comprehend." (Śäntiniketan 17) She selected fifty essays for translation and they are beautifully linked together: "One after another they journey onwards and reveal the means to arrive at the abode of peace, Sāntiniketan." (p. 27)

The book is organized in two major sections: Introduction and Translation of the fifty selected essays, followed by Notes, Glossary, Works Cited, Further Reading, and Index. In his Introduction, the translator focused on several relevant ideas which should enlighten the reader and provide joy in the process of understanding Tagore's voice. "He interpreted the Upanishadic words using the knowledge and experiences of truths as perceived in his own life." (p. 9) From there, we can segue to what is arguably quite essential in this context. When referring to Tagore's "earlier phase as a poet," the translator reveals the two dogmas: "the love and joy of the Universe" as described by Edward J. Thompson in his Rabindranath Tagore: His Life and Work. (p. 81) (quoted on p. 8) The logical conclusion, in the translator's view, is that "Without love there is no bliss or joy because it is only love which brings about the overwhelming feeling of joy or bliss." (p. 8)

In Tagore's novel Gora (1910), the translator invites the reader to find love as "a dominant figure" in a poignant description of Gora's love for his mother:

Mother, you are my mother! The mother whom I have been wandering about in search of was all the time sitting in my room at home. You have no caste, you make no distinctions, and have no hatred - you are only the image of our welfare! (407) (Śāntiniketan 9)

The present volume is a solid exploration of Tagore's "ideas of universality, his socio-cultural location along with the development of his thought, his reflections on Buddhism, Vaisnavism, Baul philosophy, the Bhagavadgita and to a great extent the Upanishads and their contemporary relevance." (Flyer, Bhattacharyya, 2020) The plethora of scholarly research makes this book unique, as the author is also the translator of the essays presenting the reader an original contribution to Tagore's extremely valuable "meditations on life, nature, religion, philosophy and the world at large." (Flyer, Bhattacharyya, 2020)

The whole project takes the reader on a journey of discovery. The translator brings to the foreground novel ideas which make Śäntiniketan essays a treasure trove of minute, detailed information expertly presented in this book. A perfect example would be Tagore's concept of harmony between opposites. According to Bhattacharyya, Sri Ramakrishna's concept of vijñana and bhavamukha may be connected to Tagore's philosophy, making this approach the first of its kind to assert the connection. (Śāntiniketan 14)

The relevance of the examples used by Tagore, when he referred to the natural sciences, The Bible, The Upanishads, The Gita, as well as other sources, will definitely serve as a very practical guide to the readers of these essays who are looking for ways to turn adversities into meaningful life experiences. Two essays, in succession, can carry forward a profound and smooth flow of ideas. The essay entitled 'Dedication' probes into the following question: "What happens in the path of sadhana?" (Śäntiniketan 36). The impending difficulties and the unexpected obstacles, says Tagore, can be overcome when we find ourselves on the journey 'along the desert path of dryness and emptiness, without taking any food or even without getting anything.' (p. 94) Right next to it, the essay entitled 'The Function of Dedication' follows the same path when the message conveyed is that the meditation itself makes the journey successful. It is the Dedication which 'overcomes hopelessness, the Dedication which has the capacity to withstand shock, the Dedication indifferent to external encouragement, and the Dedication unmoved by criticism - at no cost, for no reason should that Dedication renounce us.' (Śāntiniketan 97) 
The power of the word - written, oral, or chanted - is pivotal and proves Tagore's vocabulary prowess. The translator lays claim that "Tagore uses and repeats certain words, which emphasize his focus and deliver a flow to the whole collection. Economic terms are used, like wealth, save, need, want, poverty lost, lack and borrow; words dealing with the idea of celebration: festival, celebration, mela, fair; words related to the time of day: day, night, morning, evening, dawn, and dusk; legal terms like justice and injustice; other words become titles of other essays: lack, sin, sorrow, renunciation, power, prayer, beauty, prana, end, muki." (Śäntiniketan 27) The wealth of such vocabulary words has enduring power, especially if they can synthesize knowledge in concise and meaningful messages. "If the collection of the selected essays is considered to be a single sentence, then each of these essays functions as a part of speech." (ibid 27)

In order to attain effective 'communication through translation,' (Datta 120-121, quoted on page 42) the translator's linguistic achievement is rendered successfully in its full transliteration and, at the same time, made easily accessible not only to the target audience, mainly non-Bengali, but to the international English avid readers as well. The section of Readership clarifies it even further: "The translation of the Śantiniketan essays is aimed at both the national (non-Bengali) and the international target readership. For the Indian readership, certain culture-specific terms and quotations were retained in transliteration. But for the non-Indian and Indian diaspora (by birth) readers, endnotes and a glossary were furnished." (Śāntiniketan 42)

Along the same lines, in his comments related to Tagore's prose style, the translator resorts to a persuasive argument that the readers will notice that "a particular idea was very carefully and beautifully interwoven in a long sentence and by simply breaking the sentence into smaller ones, the charm, the flow and the emphasis of the original would invariably be lost." (Śäntiniketan 46) To add credence to his argument, the translator notes what Buddhaveda Bose observed about Tagore's prose style:

... In Tagore the unit is the paragraph, and the link between the paragraphs and the sentences of which they are composed, is provided not merely by grammar or logical coherence, but by another element, less easy to define, which remains off stage as it were and yet animates the whole. (Bose, 1961, p. 112) (Quoted on page 46)

When the literal meaning did not convey the exact intended meaning, certain nuances were transposed and collocations altered in order to keep the text faithful to its original. When punctuation was involved, as Bose gracefully contends, "It was Tagore who showed how much Bengali can gain in speed, strength and richness by adopting parentheses, inversions and several other devices which are common in English and all other languages which have developed a prose literature." (Bose, 1961, p. 112) (quoted on p. 47)

The Śantiniketan essays were originally meant for the audiences rather than for the readers, so great efforts were made to retain their "rich tonal quality" (Śāntiniketan 47) in the translation.-To bridge the gap between the written record and its distinctive sound pattern, great care was necessary to arrange the words in a sequence that makes the reading out loud a pleasant and delightful experience. When recited, Tagore's words are threaded together and obviously become even more powerful.

Let several quotations speak for the exquisite beauty of the translated essays. First, we can all relate to the reciprocal value of the parts and whole:

When man attempts to see the whole all at once, he sees it hazily, hence he first sees it in parts and unites the parts into the whole. For this reason, if he sees only the parts and completely denies the whole, then he has to be seriously answerable for that; again, if he only aims at the whole and completely ignores the parts then that emptiness becomes totally futile for him. (10 January 1909) (The Whole, p. 78)

Additionally, any reader would definitely enjoy the precious moments of discovery when letters become words and words acquire meaning:

During childhood, while learning each letter $k a, k h a, g a$, independently in the Varna parichay, I derived no joy from them. That is because I could not get any meaning in those independent letters. After that when the letters were joined together to form words such as kara, khala and the like, then as the letters revealed their significance, my mind started to experience joy to some extent. But, such disjointed words cannot provide sufficient interest to the mind; they bring about pain and weariness. Then, even today I clearly remember the day when I read the words water drips, leaves quiver, I derived immense joy on that day; because the words then became replete with deeper meanings. Now, my mind does not derive any pleasure in merely reciting water drips, leaves quiver, it rather gives me a feeling of displeasure. Now I wish to realize the syntaxes which have significance only in sentences with deeper meanings. (27 February 1909) (Detachment, p. 91)

Furthermore, we are all made aware of the intrinsic value of a good poem and its profound effect on the reader: 
In a song there is the terminal point of a measure, in prosody there is a caesura, and even in this very writing, the authority of the full stop is in no way inferior to the other parts of the writing. These very full stops have steered this writing - they are not allowing this writing to meander constantly into aimlessness.

In fact, when a poem comes to an end, even that ending itself is a major part of the poem. This is because a good poem never ends in a void. Even where it ends, it speaks; these unspoken words must be given the scope to express themselves. (September/October 1910) (End, p. 119)

Notes (pp. 128-141): In this section, the translator wrote her comprehensive notes for the essays, and from "Arise! Awake!" to "Innermost Peace," detailed explanations help the reader not only to better understand the vocabulary words, the concepts, and the titles of the essays, but also to assess the high caliber and the originality of the whole project. We all learn, for example, that 'The word 'karma' has been translated in these essays to mean 'acts', 'activities', 'actions' and 'work' depending on the context. (p. 128) By the same token, we are informed that 'Uttering the word 'satyam' three times in succession means to swear an oath or promise by three solemn affirmations." (p. 135)

The Glossary (pp. 142-144) adds a special touch because it teaches the reader how to understand a rich culture that effected a profound influence on other cultures across the world. Just a few examples should suffice:

amrita: divine nectar of immortality obtained by the churning of the ocean [...] myth of the Samudra Manthana ('Churning of the Ocean'). (p. 142)

namaskar: the act of bowing and folding the elbows at right angles and joining the palms of both hands together touching each other in front of the chest, parallel to the heart [...] with finger tips pointing upward. It is a sign of reverence to those that are superior to oneself. (p. 143)

satyam: a Sanskrit word which means 'Truth.' (p. 144)

In order to facilitate the reader's understanding of Tagore's Śäntiniketan essays as presented in this scholarly approach, the following words and concepts are also necessary for a worthwhile cultural experience:

ashram - a hermitage, monastic community, or any other place of religious retreat.

mela - a Sanskrit word meaning 'gathering'.

mukti - freedom or liberation or ultimate liberation 'moksha' depending on the context. (Śantiniketan 143)

prana - a universal energy which flows in currents in and around the body.

sadhana - means spiritual practice.

sloka - a poetic form used in Sanskrit, the classical language of India.

upāsanā - means worship.

Although the remarkable value of the Śantiniketan essays might be mainly intended for scholars and researchers of Translation Studies, in equal measure, the fundamental depth and power of the meditations presented in this volume will also provide an insightful analysis of Tagore the essayist, and will attest to the staying power of the "profound religious, spiritual, and philosophical knowledge in his own voice." (Flyer, Bhattacharyya, 2020)

\section{References}

Bhattacharayya, M. (2020). Rabindranath Tagore's Śāntiniketan Essay: Religion, Spirituality and Philosophy. London \& New York: Routledge

Bose, B. (1961). "Rabindranath Tagore and Bengali Prose.” A Centenary Volume: Rabindranath Tagore. New Delhi: Sahitya Akademi. 102-113.

Datta, S. (2009). Exploration in Tagore Translation. Kolkata: Bagchi

Tagore, R. (1980). Fruit-Gathering. New Delhi: Macmillan

(1912). Gitanjali: Song Offerings. The India Society of London

(1909). Gora. New Delhi: Macmillan

(1919). The Home and the World. New Delhi: Macmillan

(2001). "Sanyasi, or the Ascetic." Collected Poems and Plays of Rabindranath Tagore. Trans. Rabindranath

Thompson, E. J. (1921). Rabindranath Tagore, His Life and Work. Association Press (YMCA). 